\title{
Characteristics of dual carbapenemase-producing Klebsiella pneumoniae strains from an outbreak in Venezuela: a retrospective study
}

\author{
Dianny Martínez, ${ }^{1}$ Luisa Caña, ${ }^{1}$ Hectorina Rodulfo, ${ }^{2}$ José García, ${ }^{1}$ Diorelis González, ${ }^{1}$ \\ Lucy Rodríguez, ${ }^{1}$ and Marcos De Donato ${ }^{2}$
}

Suggested citation Martínez D, Caña L, Rodulfo H, García J, González D, Rodríguez L, et al. Characteristics of dual carbapenemase-producing Klebsiella pneumoniae strains from an outbreak in Venezuela: a retrospective study. Rev Panam Salud Publica. 2020;44:e50. https://doi.org/10.26633/RPSP.2020.50

ABSTRACT Objective. To characterize carbapenemase-producing Klebsiella pneumoniae isolated from patients treated at a hospital in Cumaná, Sucre, Venezuela.

Methods. This was a retrospective study conducted at the general hospital in Cumaná where $58 \mathrm{~K}$. pneumoniae strains were analyzed for resistance to antimicrobials, specifically carbapenems, in January - June 2015. Production of metallo- $\beta$-lactamases and serine carbapenemases was determined by the double-disc synergy test, using EDTA-sodium mercaptoacetic acid and 3-aminophenyl boronic acid discs, respectively. Multiplex-PCR was used to detect genes coding for carbapenemases. Molecular typing using ERIC-PCR determined the presence of clones.

Results. Four strains of $K$. pneumoniae resistant to carbapenems were identified. Phenotypic methods for detection of metallo- $\beta$-lactamases and serine carbapenemases were positive, and PCR demonstrated the

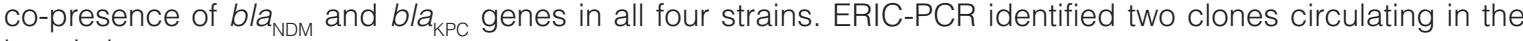
hospital.

Conclusions. Infection control strategies are needed at the central hospital in Cumaná and its surrounding areas to prevent the spread of these pathogens, especially given the high levels of migration from Venezuela to other countries in South America.

Keywords Klebsiella pneumoniae; carbapenem-resistant Enterobacteriaceae; molecular typing; Venezuela

In recent years, enterobacteria capable of producing enzymes that confer resistance to $\beta$-lactam antibiotics, including carbapenems, have appeared and dispersed worldwide (1), diminishing the therapeutic arsenal. Most of these enzymes, generically called carbapenemases, belong to three of four classes defined by Ambler's molecular classification (2): Class A, predominantly Klebsiella pneumoniae carbapenemase (KPC); Class B, metallo- $\beta$-lactamases (MBL) dependent on zinc, including IMiPenemase (IMP), New Delhi MBL (NDM), and Verona
Integron-encoded MBL (VIM); and Class D, mostly oxacillinases (OXA).

The enterobacteria producing these enzymes have become an emerging clinical and public health problem, continuously evolving with a high rate of intra- and interhospital dissemination, which makes treatment and control difficult $(3,4)$. Mortality rates in cases of carbapenemases-producing Klebsiella pneumoniae (CPKP) infection are high, ranging from $18 \%-60 \%$, with the highest rates in patients with bacteremia $(5-7)$.

\footnotetext{
1 Clinical Bacteriology Laboratory, Antonio Patricio de Alcalá University Hospital, Cumaná, Venezuela.
} 
Inadequate empirical antibiotic treatment increases the likelihood of a poor clinical outcome, whereas multi-drug therapy and control or elimination of the source of infection are associated with better patient survival (5).

KPC was first reported and described in 2001 in K. pneumoniae in North Carolina, United States (8). Rapid dissemination of strains of CPKP dramatically changed the global epidemiological context. Although KPC is presently reported mostly in K. pneumoniae, it has also been described in other bacterial species, such as Escherichia coli, Serratia marcescens, Citrobacter spp., Enterobacter spp., Pseudomonas aeruginosa, P. putida, and Acinetobacter spp. (4).

Since 2008, the spread of microorganisms has been documented worldwide due to NDM, an MBL that causes resistance to all $\beta$-lactam antibiotics except aztreonam. The first NDM was identified in strains of K. pneumoniae and E. coli isolated from a Swedish patient who had visited India and Pakistan $(9,10)$. Due to the spread of microorganisms with NDM-like resistance mechanisms among numerous bacterial species and geographic regions, the Pan American Health Organization / World Health Organization (PAHO / WHO) has underscored the importance of strengthening surveillance and establishing control strategies (11).

Carbapenemase-producing Enterobacteriaceae strains with extensive resistance and pan-resistance are currently one of the greatest threats to the general population, and especially to patient health. Quantifying the number of existing cases and the extent of clonal dissemination across various geographic locations is necessary for control strategies. The present research aimed to characterize carbapenemase-producing Klebsiella pneumoniae isolated from patients treated at the central hospital in Cumaná, Sucre, Venezuela.

\section{MATERIALS AND METHODS}

All carbapenems-resistant K. pneumoniae strains isolated in January - June 2015 were collected by bacteriology laboratory staff from samples of hospitalized patients receiving long-term treatment at the Antonio Patricio de Alcalá University Hospital (HUAPA). HUAPA is the main hospital for Cumaná city, in the state of Sucre, Venezuela; it is also the state reference center.

\section{Bacteriological diagnostics}

The viability and purity of the strains were verified following conventional procedures and established identification procedures for enterobacteria (12). Antimicrobial susceptibility was performed using the disc diffusion method (13). In accordance with guidelines established by the Clinical and Laboratory Standard Institute (14), the following categories of antimicrobials were tested using Oxoid products (Oxoid Ltd., ThermoFisher Scientific Inc., Waltham, MA, United States): aztreonam (30 $\mu \mathrm{g})$, ceftazidime $(30 \mu \mathrm{g})$, ceftriaxone $(30 \mu \mathrm{g})$, cefepime $(30 \mu \mathrm{g})$, imipenem (IMP; $10 \mu \mathrm{g}$ ), meropenem (MEM; $10 \mu \mathrm{g}$ ), amoxicillin/ clavulanic acid $(30 \mu \mathrm{g})$, ampicillin/sulbactam $(20 \mu \mathrm{g})$, piperacillin/tazobactam $(10 \mu \mathrm{g})$, amikacin $(30 \mu \mathrm{g})$, ciprofloxacin $(5 \mu \mathrm{g})$, and sulfamethoxazole-trimethoprim (1.25 $\mathrm{g} / 23.75 \mu \mathrm{g})$.

\section{Phenotypic detection of carbapenemases}

For detection of MBL, the double disc synergy test (DDST) was used as described by Lee and colleagues (15) with IMP
$(10 \mu \mathrm{g})$, MEM $(10 \mu \mathrm{g})$, and sodium ethylenediaminetetraaceticmercaptoacetic acid (750 $\mu \mathrm{g}$ EDTA / 2 mg SMA) discs. The EDTA-SMA disc was placed in the center of the plate, at a distance of $15 \mathrm{~mm}$ from the IMP and MEM discs. A test was considered to be positive for production of an MBL when the increase in the inhibition halo was visible between the $\beta$-lactam and the EDTA-SMA discs.

For detection of serine carbapenemases, DDST was used as proposed by Pasteran and colleagues (16) with IMP $(10 \mu \mathrm{g})$, MEM $(10 \mu \mathrm{g})$, and 3-aminophenyl boronic acid (APB $300 \mu \mathrm{g}$ ) discs. The APB disc was placed in the center of the plate and on both sides, at a distance of $15 \mathrm{~mm}$ from the IMP and MEM discs. The plates were incubated at $35{ }^{\circ} \mathrm{C}$, in aerobiosis for $18 \mathrm{hrs}$, and a test was considered to be positive for the production of a serine carbapenemases when an increase of the inhibition halo was visible between the $\beta$-lactam (MEM and/or IMP) and the APB discs.

\section{Molecular characterization of the strains}

The strains showing production of carbapenemases were preserved in Luria Bertani agar and transferred to the molecular genetics laboratory at the Instituto de Investigaciones en Biomedicina y Ciencias Aplicadas de la Universidad de Oriente for molecular study. DNA was extracted from pure cultures of K. pneumoniae strains using the Wizard ${ }^{\circledR}$ Genomic DNA Purification kit (Promega Corporation, Madison, WI, United States), following the manufacturer's specifications.

Multiplex polymerase chain reaction (PCR) was used according to the protocol described by Poirel and colleagues (17) to

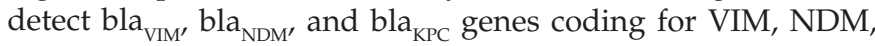
and KPC carbapenemases, respectively.

For the molecular characterization, Enterobacteria Repetitive Intergenic Consensus sequences (ERIC)-PCR was used in the strains carrying carbapenemases genes, according to the protocol published by Versalovic and colleagues (18).

The visualization of the amplification products of the carbapenemases genes was carried out by electrophoresis in $2 \%$ agarose gels, stained with GelRed (10 000 X) in 1X TBE buffer for 30 minutes at 100 volts, while ERIC-PCR, was carried out in $3 \%$ agarose gels run for $3 \mathrm{hrs}$ at 50 volts. To estimate the size of the resulting DNA fragments, a $100 \mathrm{bp}$ molecular weight marker was used. The resulting bands were detected by transillumination with ultraviolet light, and photographed.

\section{Quality control}

The certified strains used for quality control of the antimicrobial tests were E. coli ATCC $^{\circledR} 25922^{\mathrm{TM}}$ (American Type Culture Collection, Manassas, Virginia, United States) and P. aeruginosa ATCC $27853^{\mathrm{TM}}$ were used for quality control of the antimicrobial tests. For the multiplex PCR, a strain from clinical origin: E. coli 1159-15HUAPA producing NDM and KPC was used as a positive control. E. coli ATCC ${ }^{\circledR} 25922^{\mathrm{TM}}$ was used as a negative control.

\section{Data analysis}

The antimicrobial susceptibility profiles of the K. pneumoniae strains and carbapenemases detection were determined by descriptive statistics. To analyze the banding patterns obtained 
by ERIC-PCR, dendrograms were constructed using BioNumerics version 7.5 software (19), based on the Dice similarity coefficient and the Unweighted Pair-Group Method with Arithmetic mean matrix (20).

Ethics. Patient and isolate information were handled according to the bioethics and biosafety standards established by the Bioethics and Biosafety Commission of the Instituto de Investigaciones en Biomedicina y Ciencias Aplicadas de la Universidad de Oriente, Cumaná, Sucre, Venezuela.

\section{RESULTS}

The study obtained a total of 58 isolates of K. pneumoniae, of which 4 exhibited carbapenem resistance. As shown in Table 1, these 4 strains were isolated from four patients from $14-30$ years of age who presented with healthcare-associated infections (HAIs) while being treated in the hospital's Intensive Care Unit (ICU; $2^{\text {nd }}$ floor), Surgical Unit ( $8^{\text {th }}$ floor), or Medical/Surgical Unit ( $7^{\text {th }}$ floor). These strains were characterized by presenting resistance to all antimicrobial agents tested, with the exception of $\mathrm{Kp} 1$, which was also susceptible to sulfamethoxazole-trimethoprim (Table 1).

The phenotypic method, DDST, was positive for both metallo- $\beta$-lactamases and serine carbapenemases in all 4 strains. Simultaneous detection of $b l a_{\mathrm{NDM}}$ and $b l a_{\mathrm{KPC}}$ genes was evident by multiplex PCR, observing amplified fragments of $621 \mathrm{bp}$ and $798 \mathrm{bp}$ for these genes, respectively (Figure 1-A). Presence of the bla ${ }_{\mathrm{VIM}}$ gene was not detected.

Gram staining of the skin and soft tissue samples (isolates $\mathrm{Kp} 2$ and Kp3) indicated the presence of polymorphonuclear leukocytes, a clear indication of an infectious process. In addition, strains $\mathrm{Kp} 2$ and $\mathrm{Kp} 3$ were isolated in pure cultures, making it highly likely that these strains were causing infection.

Molecular typing by ERIC-PCR showed that strains Kp2, $\mathrm{Kp} 3$, and $\mathrm{Kp} 4$ had an indistinguishable banding pattern $(100 \%$ similarity), corresponding to one clone (clone b); whereas strain Kp1 (clone a) showed $<60 \%$ similarity to clone b (Figure 1-B and 1-C).

\section{DISCUSSION}

The dissemination of carbapenem-resistant K. pneumoniae in the hospital environment is the main cause of treatment failure and increased morbidity and mortality rates among patients in developing countries (7). In this study, the four patients with $\mathrm{NDM}+\mathrm{KPC}$ K. pneumoniae strains had a common characteristic: current or previous admission to the ICU—described as a risk factor for acquiring multidrug resistant bacteria due to the unit's high number of invasive procedures and prolonged use of broad-spectrum antimicrobials $(21,22)$. In addition, K. pneumoniae is considered an important cause of acquired infections in ICUs. In several investigations, admission or pre-admission to the ICU have been associated with colonization or infection by carbapenems-resistant K. pneumoniae (23 - 24). Although advanced age is considered a risk factor for acquiring carbapenem-resistant enterobacteria (23), in the present study none of the patients were elderly. NDM + KPC K. pneumoniae have been found to cause infections regardless of patient age in other studies (25). However, two patients had underlying diseases (systemic lupus erythematosus and diabetes mellitus) that compromise immunity and favor the

TABLE 1. Clinical and epidemiological data of patients from whom NDM-KPC-producing K. pneumoniae strains (Kp1 - 4) were isolated in January - June 2015 at the main hospital in Cumaná, Sucre, Venezuela

\begin{tabular}{|c|c|c|c|c|c|c|c|c|c|c|}
\hline Strain & $\begin{array}{l}\text { Patient age } \\
\text { (years) }\end{array}$ & $\begin{array}{l}\text { Patient } \\
\text { gender }\end{array}$ & Unit & Admittance date & Isolation date & Clinical diagnosis & $\begin{array}{l}\text { Antimicrobial } \\
\text { treatment }\end{array}$ & Type of sample & Resistance & $\begin{array}{l}\text { Clinical } \\
\text { outcome }\end{array}$ \\
\hline Kp1 & 30 & $\mathrm{~F}$ & ICU & 31 March 2015 & 29 April 2015 & $\begin{array}{l}\text { - Hypertensive crisis } \\
\text { - Hemorrhagic stroke } \\
\text { - } \text { Systemic lupus } \\
\text { erythematosus } \\
\text { - } \text { Chronic kidney } \\
\text { disease on } \\
\text { hemodialysis }\end{array}$ & $\begin{array}{l}\text { Piperacillin- } \\
\text { tazobactam }\end{array}$ & $\begin{array}{l}\text { Central venous } \\
\text { catheter tip }\end{array}$ & $\begin{array}{l}\text { AMC, CAZ, CRO, } \\
\text { FEP, IPM, MEM, } \\
\text { TZP, SAM, ATM, } \\
\text { CIP, NAL }\end{array}$ & $\begin{array}{l}\text { Death } \\
30 \text { April } 2015\end{array}$ \\
\hline Kp2 & 20 & M & $\begin{array}{l}\text { Surgical } \\
\text { (ICU } 26 \\
\text { April 2015) }\end{array}$ & 30 April 2015 & 18 May 2015 & $\begin{array}{l}\text { Wound by firearm } \\
\text { in the gluteus } \\
\text { penetrating the } \\
\text { abdominal cavity. }\end{array}$ & $\begin{array}{l}\text { Metronidazole, } \\
\text { meropenem, } \\
\text { Piperacillin- } \\
\text { tazobactam, } \\
\text { ciprofloxacin }\end{array}$ & $\begin{array}{l}\text { Secretion from } \\
\text { abdominal } \\
\text { wound }\end{array}$ & $\begin{array}{l}\text { AMC, CAZ, CRO, } \\
\text { FEP, IPM, MEM, } \\
\text { TZP, SAM, ATM, } \\
\text { CIP, SXT, NAL }\end{array}$ & $\begin{array}{l}\text { Improvement, } \\
\text { medical } \\
\text { discharge }\end{array}$ \\
\hline Kp3 & 14 & $\mathrm{~F}$ & $\begin{array}{l}\text { Medical/ } \\
\text { Surgical } \\
\text { (ICU } 12 \\
\text { December } \\
\text { 2014) }\end{array}$ & 21 May 2015 & 3 June 2015 & $\begin{array}{l}\text { - Abscessed cellulitis } \\
\text { in intergluteal region } \\
\text { - Type I Diabetes } \\
\text { Mellitus } \\
\text { - Mycotic vaginitis }\end{array}$ & $\begin{array}{l}\text { Oxacillin, } \\
\text { metronidazole, } \\
\text { amikacin, } \\
\text { clindamycin, } \\
\text { ciprofloxacin, } \\
\text { fluconazole }\end{array}$ & $\begin{array}{l}\text { Secretion from } \\
\text { ulcer on the } \\
\text { gluteus }\end{array}$ & $\begin{array}{l}\text { AMC, CAZ, CRO, } \\
\text { FEP, IPM, MEM, } \\
\text { TZP, SAM, ATM, } \\
\text { CIP, SXT, NAL }\end{array}$ & $\begin{array}{l}\text { Improvement, } \\
\text { medical } \\
\text { discharge }\end{array}$ \\
\hline Kp4 & 26 & M & ICU & 1 June 2015 & 10 June 2015 & $\begin{array}{l}\text { - Severe traumatism } \\
\text { skull-encephalic } \\
\text { - Wound by firearm in } \\
\text { abdominal region } \\
\text { - Peritonitis } \\
\text { - Intubated, mechanical } \\
\text { ventilation }\end{array}$ & $\begin{array}{l}\text { Ceftazidime, } \\
\text { vancomycin }\end{array}$ & $\begin{array}{l}\text { Bronchial } \\
\text { secretion }\end{array}$ & $\begin{array}{l}\text { AMC, CAZ, CRO, } \\
\text { FEP, IPM, MEM, } \\
\text { TZP, SAM, ATM, } \\
\text { CIP, SXT, NAL }\end{array}$ & $\begin{array}{l}\text { Improvement, } \\
\text { medical } \\
\text { discharge }\end{array}$ \\
\hline
\end{tabular}

Note: Abbreviations = Intensive care unit (ICU), amoxicillin-clavulanic acid (AMC), ceftazidime (CAZ), ceftriaxone (CRO), cefepime (FEP), imipenem (IPM), meropenem (MEM), piperacillin-tazobactam (TZP), ampicillin-sulbactam (SAM), aztreonam (ATM), ciprofloxacin (CIP), sulfamethoxazole-trimethoprim (SXT), nalidixic acid (NAL).

Source: Prepared by the authors from the study results. 
FIGURE 1. Molecular characterization of $K$. pneumoniae strains (Kp1 - 4) isolated in January - June 2015 from the main hospital in Cumaná, Sucre, Venezuela

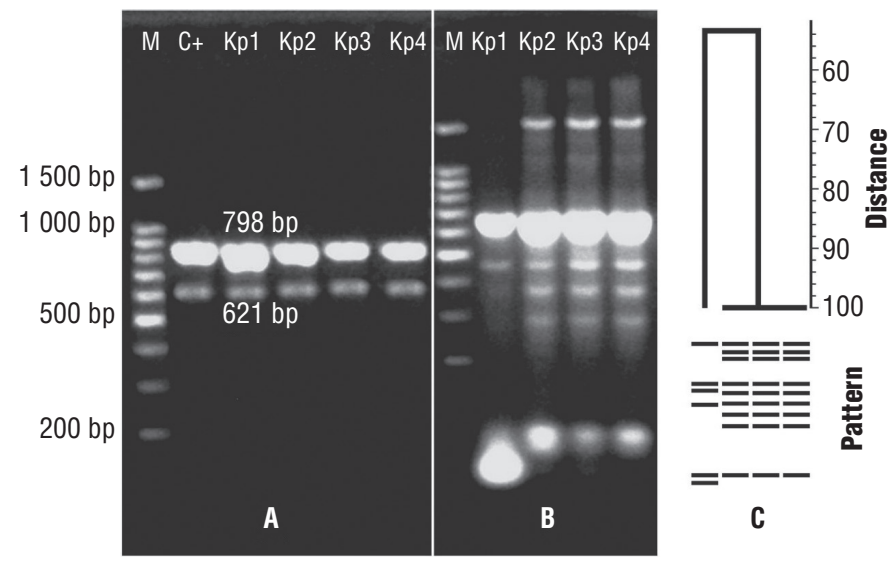

A. Amplified products of the bla gene $(798 \mathrm{pb})$ and bla marker $100 \mathrm{pb}(\mathrm{M})$ and $E$. coli $1159-15 \mathrm{HUAPA}$ as positive control $\left(\mathrm{C}_{+}\right)$

B. Molecular pattern by ERIC-PCR, with molecular weight marker $100 \mathrm{pb}(\mathrm{M})$

C. Dendrogram constructed using BioNumerics 7.5 , with similarity scale on the right Source: Prepared by the authors from the study results.

establishment/development of infections and death by these multidrug resistant bacteria (26).

Mortality rates in patients with carbapenemase-producing K. pneumoniae infections are reported to be high (5), but in this study, only one of the four patients died. In Latin America, a $64 \%$ mortality rate from blood infections has been attributed to carbapenemase-producing enterobacteria (27). Khajuria and colleagues (25) indicate that mortality from this pathogen is dependent on a variety of factors such as underlying disease, nutritional status, and medical treatment, which explains the discrepancies in mortality rates observed by different studies.

Nevertheless, the three patients who recovered did not receive the recommended antimicrobial treatment for carbapenemaseproducing K. pneumoniae: continuous intervenous infusion of a high dose of one carbapenem (usually meropenem) in combination with a non- $\beta$-lactam, such as colistin, tigecycline, or fosfomycin (28).

The association of $b l a_{\mathrm{NDM}}$ with another carbapenem resistance gene, such as $b l a_{\mathrm{KPC}}$, is worrisome and demonstrates the rapid evolution of the bacteria to acquire different resistant genes in the hospital setting (26). Similar reports of co-producing NDM + KPC have been made in India in K. pneumoniae (29), China in Citrobacter freundii (30), and Brazil in Enterobacter hormachei, Providencia rettgeri, and E. coli (31). In Venezuela, according to our literature review, there are no previous reports of isolates with simultaneous presence of these resistant genes, only co-production of KPC + VIM $(32,33)$. However, there are previous reports of NDM-producing E. coli (34) and K. pneumoniae (35). More specifically, there is a history of isolation of $E$. coli with $b l a_{\mathrm{NDM}}$ in Cumaná (36) and of K. pneumoniae with $b l a_{\mathrm{KPC}}$ in its general hospital (37).

Similarities in the dissemination and spectrum of antimicrobial resistance for $b l a_{\mathrm{NDM}}$ and $b l a_{\mathrm{KPC}}$ genes (both confer resistance to virtually all $\beta$-lactams) imply that these genes are found in similar mobile genetic elements (29). The $b l a_{\mathrm{NDM}}$ and $b l a_{\mathrm{KPC}}$ genes generally have been reported in conjugative plasmids (9), allowing the transfer and rapid spread of these genes and other resistance determinants of plasmid localization. When microorganisms with both genes coexist in the hospital environment, it is highly likely that they end up in the same host, as was found in the present study.

The four strains were also resistant to ciprofloxacin, sulfamethoxazole-trimethoprim, and amikacin. Other reports have shown that plasmids carrying the carbapenem-resistant genes also contain a variety of determinants of resistance to other antimicrobials, including genes encoding $\beta$-lactamases, quinolone resistance, and 16S RNA methylases that confer resistance to aminoglycosides (26). So, a specific antibiotic drug could be selected, not only for its resistance to the molecule being used, but also to other antimicrobials; nevertheless, copresence of carbapenemases makes selecting the best treatment for these patients very difficult. In countries with high incidence of carbapenemase-producing enterobacteria, resistance to last-line antimicrobials, such as colistin and tigecycline, has been observed (38).

In any hospital, the dissemination of carbapenem-resistant K. pneumoniae is complex and may involve the same clone or different unrelated isolates spreading among patients (37). The ERIC-PCR tests in this study showed the presence of a single clone circulating in three hospital units during May - June 2015. It should be noted that the first isolation of NDM + KPC K. pneumoniae, although not related to this clone, was isolated in the ICU and, as previously stated, the common factor among the patients was their stay in this unit. So, it could be inferred that dissemination occurred from the ICU to the two other units, and not vice-versa. These results concur with another genotyping study of carbapenem-resistant K. pneumoniae, which used pulsed field electrophoresis and found clone dissemination in 2009 and 2013 in the ICU of the same hospital (37). Other researchers worldwide have also reported the spread of a clone of NDM-1-producing K. pneumoniae in ICUs (25), confirming that hospitalization in the ICU is a determining risk factor for the acquisition and dissemination of these pathogens.

Limitations. Due to financial limitations and accessibility to sequencing centers, we could not determine the clonal group to which these species belong. It has been reported, however, that the clonal type ST258 is associated with the rapid spread of $b l a_{\mathrm{KPC}}$-carrying $\mathrm{K}$. pneumoniae; however, to date there are no reports of ST258 strains carrying the $b l a_{\mathrm{NDM}}$ gene $(41,42)$. Also, strains with $b l a_{\mathrm{KPC}}$ not belonging to ST258 (43) have been isolated, meaning that this clone could belong to ST258 or any other clone. In addition, since colistin and tigecycline are not available for treatment nor testing in Venezuela, the study did not consider resistance to these last-line options.

\section{Conclusions}

The present study is the first report of K. pneumoniae with simultaneous presence of $b l a_{\mathrm{NDM}}$ and $b l a_{\mathrm{KPC}}$ genes in Venezuela. The emergence of bacteria associated with these genes demonstrates the ability of these microorganisms to rapidly evolve, to acquire plasmids carrying multiple resistance genes, to persist in the hospital environment, and to spread successfully (38). These attributes make antimicrobial therapy extremely complex, especially in Venezuela where current therapeutic options are limited by economic and political crises.

High levels of migration from Venezuela to other countries gives the results of this study particular importance for all of 
South America (39). Infection control measures, such as hand washing and routine detection of rectal or perianal colonization in admitted patients (40), are urgently needed in the general hospital of Cumaná to prevent the spread of these microorganisms.

Author contributions. MD, RH, and DDM conceived the original idea and planned the experiments. MD, CL, GJ, GD, and RL collected the data on the strains and contributed to the analysis of the phenotypic data. MD and RH contributed in the molecular characterization of the strains. MD, RH, and DDM contributed in the interpretation of the results and wrote the paper. All authors reviewed and approved the final version.
Funding. This study was partially supported by a Science Mission Project G-2007001442, funded by the Ministerio del Poder Popular para la Ciencia, la Tecnología e Industrias Intermedias of Venezuela. The funders had no role in the study design, data collection or analysis, decision to publish, or preparation of the manuscript.

\section{Conflicts of interest. None declared.}

Disclaimer. Authors hold sole responsibility for the views expressed in the manuscript, which may not necessarily reflect the opinion or policy of the RPSP/PAJPH and/or PAHO.

\section{REFERENCES}

1. Grundmann H, Livermore DM, Giske CG, Canton R, Rossolini GM, Campos J, et al. Carbapenem-non-susceptible Enterobacteriaceae in Europe: Conclusions from a meeting of national experts. Euro Surveill. 2010;15(46):19711.

2. Ambler RP. The structure of $\beta$-lactamases. Philosophical Transactions of the Royal Society of London. B, Biological Sciences. 1980;289(1036):321-31.

3. Walsh TR, Toleman MA, Poirel L, Nordmann P. Metallo- $\beta$-lactamases: The quiet before the storm. Clin Microbiol Rev. 2005;18(2):306-325. doi:10.1128/CMR.18.2.306-325.2005

4. Queenan AM, Busk K. Carbapenemases: The versatile $\beta$-lactamases. Clin Microbiol Rev. 2007;20(3):440-458. doi:10.1128/CMR.00001-07

5. Petrosillo N, Giannella M, Lewis R, Viale P. Treatment of carbapenemresistant Klebsiella pneumoniae: The state of the art. Expert Rev Anti Infect Ther. 2013;11(2):159-177. doi:10.1586/eri.12.162

6. Lee GC, Burgess DS. Treatment of Klebsiella pneumoniae carbapenemase (KPC) infections: A review of published case series and case reports. Ann Clin Microbiol Antimicrob. 2012;11:32. doi:10.1186/1476-0711-11-32

7. Tzouvelekis LS, Markogiannakis A, Psichogiou M, Tassios PT, Daikos GL. Carbapenemases in Klebsiella pneumoniae and other Enterobacteriaceae: An evolving crisis of global dimensions. Clin Microbiol Rev. 2012;25(4):682-707. doi:10.1128/CMR.05035-11

8. Yigit H, Queenan A, Anderson G, Domenech A, Biddle J, Steward $C$, et al. Novel carbapenem-hydrolyzing $\beta$-lactamase KPC-1, from a carbapenem-resistant strain of Klebsiella pneumoniae. Antimicrob Agents Chemother. 2001;45(4):1151-1161. doi:10.1128/ AAC.45.4.1151-1161.2001

9. Nordmann P, Poirel L, Walsh TR, Livermore DM. The emerging NDM carbapenemases. Trends microbiol. 2011;19(12):588-95.

10. Kumarasamy KK, Toleman MA, Walsh TR, Bagaria J, Butt F, Balakrishnan R, et al. Emergence of a new antibiotic resistance mechanism in India, Pakistan, and the UK: a molecular, biological, and epidemiological study. Lancet Infect Dis. 2010;10(9):597-602.

11. Wernli D, Haustein T, Conly J, Carmeli Y, Kickbusch I, Harbarth S. A call for action: The application of The International Health Regulations to the global threat of antimicrobial resistance. PLoS Med. 2011;8:e1001022.

12. Koneman E, Winn W, Allen S, Janda W, Procop G, Schereckenberger $\mathrm{P}$, et al. Diagnóstico Microbiológico. 6th ed. Buenos Aires, Argentina: Editorial Médica Panamericana, SA; 2008.

13. Bauer AW, Kirby WM, Sherris JC, Turck M. Antibiotic susceptibility testing by a standardized single disk method. Amer J Clin Pathol. 1966;45(4):493-6.

14. Clinical and Laboratory Standard Institute (CLSI). Perfomance Standard for Antimicrobial Susceptibility Testing. Supplement M100-S21. Wayne PA, USA: Clinical and Laboratory Standard Institute; 2015.

15. Lee K, Lim Y, Yong D, Yum J, Chong Y. Evolution of the Hodge test and imipenem-EDTA double disk sinergy test for differentiating metallo- $\beta$-lactamase producing isolates of Pseudomonas spp. and Acinetobacter spp. J Clin Microbiol. 2003;41(10):4623-9.

16. Pasteran F, Mendez T, Guerriero L, Rapoport M, Corso A. Sensitive screening tests for suspected class A carbapenemase production in species of Enterobacteriaceae. J Clin Microbiol. 2009;47(6):16311639. doi:10.1128/JCM.00130-09.

17. Poirel L, Walsh TR, Cuvillier V, Nordmann P. Multiplex PCR for detection of acquired carbapenemase genes. Diagn Microbiol Infect Dis. 2011;70 (1):119-23.

18. Versalovic J, Koeuth T, Lupski J. Distribution of repetitive DNA secuence in eubacterias and application to fingerprinting of bacterial genomes. Nucleic Acids Research. 1991;19(24):6823-6831. doi:10.1093/nar/19.24.6823

19. Dice LR. Measure of the amount of ecologic associations between species. Ecology 1945;26:277-302.

20. Nei M, Li WH. Mathematical model for studying genetic variation in terms of restriction endonucleases. Proc Natl Acad Sci USA. 1979;76(10):5269-5273. doi:10.1073/pnas.76.10.5269

21. Pitout JD, Nordmann P, Poirel L. Carbapenemase- Producing Klebsiella pneumoniae, a key pathogen set for global nosocomial dominance. Antimicrob Agents Chemother. 2015;59(10): 5873-84.

22. Nordmann T, Naas T, Poirel L. Global spread of carbapenemaseproducing Enterobacteriaceae. Emerg Infect Dis. 2011;17(10):17911798. doi:10.3201/eid1710.110655.

23. Kofteridis DP, Valachis A, Dimopoulou D, Maraki S, Christidou A, Mantadakis E, et al. Risk factors for carbapenem-resistant Klebsiella pneumoniae infection/colonization: a case-case control study. J Infect Chemother. 2014;20(5):293-297. doi:10.1016/j.jiac.2013.11.007.

24. Jiao Y, Qin Y, Liu J, Li Q, Dong Y, Shang Y. Risk factors for carbapenem-resistant Klebsiella pneumoniae infection/colonization and predictors of mortality: a retrospective study. Pathog Glob Health. 2015;109(2):68-74. doi:10.1179/2047773215Y.0000000004

25. Khajuria A, Kumar A, Kumar M, Grover N, Aggarwal A. Multidrug resistant NDM-1 metallo-beta-lactamase producing Klebsiella pneumoniae sepsis outbreak in a neonatal intensive care unit in a tertiary care center at central India. Indian J Pathol Microbiol. 2014;57(1):65-68. doi:10.4103/0377-4929.130900

26. Pesesky M, Hussain T, Wallace M, Wang B, Andleeb S, Burnham C, et al. KPC and NDM-1 Genes in Related Enterobacteriaceae Strains and Plasmids from Pakistan and the United States. Emerg Infect Dis. 2015;21(6):1034-1037. doi:10.3201/eid2106.141504

27. Villegas MV, Pallares CJ, Escandón-Vargas K, Hernández-Gómez C, Correa A, Álvarez C, et al. Characterization and clinical impact of bloodstream infection caused by carbapenemase-producing Enterobacteriaceae in seven Latin American countries. PLoS One. 2016;11(4): e0154092.

28. Lee CR, Lee JH, Pak K, Kim YB, Jeong BC, Lee SH. Global dissemination of carbapenemase- producing Klebsiella pneumoniae: epidemiology, genetic context, tretment options, and detection methods. Front Microbiol. 2016;7: 895. doi:10.3389/fmicb.2016.00895

29. Kumarasamy K, Kalyanasundaram A. Emergence of Klebsiella pneumoniae isolate co-producing NDM-1 with KPC-2 from India. J Antimicrob Chemother 2012;67(1):243-244. doi:10.1093/jac/dkr431.

30. Feng J, Qiu Y, Yin Z, Chen W, Yang H, Yang W, et al. Coexistence of a novel KPC-2-encoding MDR plasmid and an NDM-1-encoding pNDM-HN380-like plasmid in a clinical isolate of Citrobacter freundii. J Antimicrob Chemother. 2015;70(11):2987-2991. doi:10.1093/ $\mathrm{jac} / \mathrm{dkv} 232$. 
31. Pereira P, Borghi M, Albano R, Lopes J, Silveira M, Marques E, et al. Coproduction of NDM-1 and KPC-2 in Enterobacter hormaechei from Brazil. Microb Drug Resist. 2015;21(2):234-6.

32. Martínez D, Marcano D, Rodulfo H, Salgado N, Cuaical N, Rodríguez L, et al. KPC and VIM producing Enterobacter cloacae strain from a hospital in northeastern Venezuela. Invest. Clin. 2015;56(2):182-7.

33. Falco A, Ramos Y, Franco E, Guzman A, Takiff H. A cluster of KPC-2 and VIM-2-producing Klebsiella pneumoniae ST833 isolates from the pediatric service of a Venezuelan Hospital. BMC Infect Dis. 2016;16(1):595. doi:10.1186/s12879-016-1927

34. De Sousa L, Chacare M, Cuaical, N, Ashby J. Primer aislamiento de Escherichia coli productora de carbapenemasa tipo New Delhi (NDM) en un hospital de Ciudad Guayana, Venezuela. A propósito de dos casos. RSVM. 2016;36: 40-5.

35. Kazmierczak K, Rabine S, Hackel M, McLaughlin R, Biedenbach D, Bouchillon S, et al. Multiyear, Multinational Survey of the Incidence and Global Distribution of Metallo-Lactamase-Producing Enterobacteriaceae and Pseudomonas aeruginosa. Antimicrob Agents Chemother. 2015;60(2):1067-1078. Published 2015 Dec 7. doi:10.1128/ AAC.02379-15

36. Delgado-Blas JF, Ovejero CM, Abadia-Patiño L, Gonzalez-Zorn B. Coexistence of mcr-1 and blaNDM-1 in Escherichia coli from Venezuela. Antimicrob Agents Chemother. 2016;60(10):6356-6358.

37. Martínez D, Araque Y, Rodulfo H, Caña L, García J, González D, et al. Relación clonal y detección del gen blaKPC en cepas de Klebsiella pneumoniae resistentes a carbapenémicos en un hospital de Venezuela. Rev Chilena Infectol. 2016;33(5):524-530. doi:10.4067/ S0716-10182016000500006

38. Escandón-Vargas K, Reyes S, Gutiérrez S, Villegas MV. The epidemiology of carbapenemases in Latin America and the Caribbean. Expert Rev Anti Infect Ther. 2017;15(3):277-297.
39. Nordmann P, Poirel L. The difficult-to-control spread of carbapenemase producers among Enterobacteriaceae worldwide. Clin Microbiol Infect. 2014;20(9):821-30.

40. Muñoz- Price L, Poirel L, Bonomo RA, Schwaber MJ, Daikos GL, Cormican M, et al. Clinical epidemiology of the global expansion of Klebsiella pneumoniae carbapenemases. Lancet Infect Dis. 2013;13(9): 785-96.

41. Grundmann H, Glasner C, Albiger B, Aanensen DM, Tomlinson CT, Andrasević AT, et al. European Survey of Carbapenemase-Producing Enterobacteriaceae (EuSCAPE) Working Group. Occurrence of carbapenemase-producing Klebsiella pneumoniae and Escherichia coli in the European survey of carbapenemase-producing Enterobacteriaceae (EuSCAPE): a prospective, multinational study. Lancet Infect Dis. 2017;17(2):153-163

42. Rojas LJ, Wright MS, De La Cadena E, Motoa G, Hujer KM, Villegas MV, Adams MD, Bonomo RA. Initial Assessment of the Molecular Epidemiology of blaNDM-1 in Colombia. Antimicrob Agents Chemother. 2016;60(7):4346-50.

43. Rojas LJ, Weinstock GM, De La Cadena E, Diaz L, Rios R, Hanson $\mathrm{BM}$, et al. An Analysis of the Epidemic of Klebsiella pneumoniae Carbapenemase-Producing K. pneumoniae: Convergence of Two Evolutionary Mechanisms Creates the "Perfect Storm". J Infect Dis. 2017;217(1):82-92.

Manuscript received on 20 October 2019. Revised version accepted for publication on 12 March 2020

\section{Características de las cepas de Klebsiella pneumoniae que producen dos carbapenemasas en un brote en Venezuela: un estudio retrospectivo}

RESUMEN Objetivo. Caracterizar la Klebsiella pneumoniae productora de carbapenemasa aislada de pacientes tratados en un hospital de Cumaná (Sucre, Venezuela).

Métodos. Se hizo un estudio retrospectivo en el hospital central de Cumaná, donde se analizaron 58 cepas de k. pneumoniae para estudiar la resistencia a los antimicrobianos, específicamente a los fármacos carbapenémicos, entre enero y junio del 2015. La producción de metalo- $\beta$-lactamasas y carbapenemasas de serina se determinó mediante la prueba de sinergia de doble disco, usando discos de EDTA SMA de sodio y de ácido borónico 3 aminofenil, respectivamente. Se usó la PCR múltiple para detectar la codificación de genes correspondiente a las carbapenemasas. Se determinó la presencia de clones por tipificación molecular mediante la técnica de ERIC PCR.

Resultados. Se detectaron cuatro cepas de K. pneumoniae resistentes a los fármacos carbapenémicos. Los métodos fenotípicos para la detección de metalo- $\beta$-lactamasas y carbapenemasas de serina fueron positivos y se demostró mediante la PCR la copresencia de los genes bla ${ }_{N D M}$ y bla $a_{K P C}$ en las cuatro cepas. Por medio de la técnica ERIC-PCR se detectaron dos clones que circulaban en el hospital.

Conclusiones. Es necesario adoptar estrategias de control de infecciones en el hospital central en Cumaná y las zonas circundantes para prevenir la propagación de estos agentes patógenos, especialmente dados los niveles altos de migración de Venezuela a otros países de América del Sur.

Palabras clave Klebsiella pneumoniae; Enterobacteriaceae resistentes a los carbapenémicos; tipificación molecular; Venezuela. 


\section{Características de cepas de Klebsiella pneumoniae produtoras de duas carbapenemases em um surto na Venezuela: um estudo retrospectivo}

RESUMO Objetivo. Caracterizar cepas de Klebsiella pneumoniae produtoras de carbapenemases isoladas de pacientes tratados em um hospital em Cumaná, Sucre, na Venezuela.

Métodos. Realizamos um estudo retrospectivo no hospital geral de Cumaná, onde 58 cepas de K. pneumoniae foram analisadas para verificar a resistência a antimicrobianos, especificamente carbapenens, entre janeiro e junho de 2015. A produção de metalo- $\beta$-lactamases e serino-carbapenemases foi determinada pelo teste de sinergia de disco duplo, usando discos de EDTA sódico-ácido mercaptoacético e ácido 3-aminofenil borônico, respectivamente. Utilizamos a PCR multiplex para detectar os genes codificadores de carbapenemases. A tipagem molecular por ERIC-PCR determinou a presença de clones.

Resultados. Foram identificadas quatro cepas de K. pneumoniae resistentes a carbapenens. Os métodos fenotípicos para a detecção de metalo- $\beta$-lactamases e serino-carbapenemases foram positivos, e a PCR demonstrou a co-presença dos genes bla $a_{\mathrm{NDM}}$ e bla $a_{\mathrm{KPC}}$ em todas as quatro cepas. A ERIC-PCR identificou dois clones que circulavam no hospital.

Conclusões. São necessárias estratégias de controle de infecções no hospital central de Cumaná e seus arredores para prevenir a disseminação destes patógenos, especialmente devido aos altos níveis de migração da Venezuela para outros países da América do Sul. 